\title{
Merger And Innovation To Improve Organization's Performance In Indonesia To Fight Industrial Revolution 4.0: Case Study Merger Bank BTPN
}

\author{
Diana Tambunan ${ }^{1}$ Sugeng Wahyudi ${ }^{2}$ Harjum Muharam ${ }^{3}$ \\ ${ }^{1}$ Administrasi Bisnis, Universitas Bina Sarana Informatika \\ ${ }^{2,3}$ FEB Universitas Diponegoro, Semarang \\ e-mail: ${ }^{1}$ diana.dtb@bsi.ac.id, ${ }^{2}$ sug_w@yahoo.com, ${ }^{3}$ hardjum@gmail.com

\begin{tabular}{ccc}
\hline Diterima & Direvisi & Disetujui \\
$13-03-2021$ & $14-03-2021$ & $15-03-2021$ \\
\hline
\end{tabular}

\begin{abstract}
An organization will conduct a merger strategy with companies that have strong technology to overcome the challenges of industrial transformation 4.0. In 2018 Bank BTPN merged with SMBCI with the hope of strengthening banking technology so that it could serve customers of various segments with various services throughout Indonesia.This research is a case study conducted at Bank BTPN which contributes to prove whether with merger, Bank BTPN's financial performance has improved. The method used is ratio analysis by comparing the financial performance of Bank BTPN before merger and after merger and the data obtained from the 2019 Annual Report and published financial statement 2020. The results showed that the merger strategy made Bank BTPN able to use assets, funding, and technology owned by SCMBI in innovating the digital banking business of Jenius banking products, BTPN Wow! and other banking products so that the post merger of Bank BTPN's financial performance has increased rapidly both in terms of assets to be the ninth largest in Indonesia, as well as $41 \%$ increase in net profit to $\mathrm{Rp} 2.9$ trillion in 2019. This research proposes the concept of business model where merged bank should take five actions: 1) Innovation Business Digital Bangking, (2) Expansion of Customer Segmentation, (3) Diversification of Products/Market, (4) Quality of Human Resources, (5)Corporate Governance.
\end{abstract}

Keywords: Industry 4.0, merger, innovation, digital banking

\section{INTRODUCTION}

The Fourth Industrial Revolution (IR 4.0) is a phenomenon that cannot be avoided by all nations of the world.The presence of fast internet and smart phones has triggered tremendous changes that have taken place in many countries. The Government of Indonesia under the Ministry of Industry of the Republic of Indonesia on April 4, 2018 launching Making Indonesia 4.0 as an integrated roadmap to implement a number of strategies in the face of the industrial revolution 4.0 era.The application of industry 4.0 is expected to bring Indonesia into the top 10 economies in 2030. Making Indonesia 4.0 has an extraordinary impact on various industries, including the banking and financial industries, giving birth to a new business model with a digital basis that produces high-quality and high-efficiency production (Kemenperin, 2018). In the era of digitalization, many companies invest in the Internet of Things so that the production process, machinery, employees and products produced can be integrated into one integrated network with data collection, data analysis, evaluation of company development and improvement of company performance (Nagy, Oláh, Erdei, Mate, \& Popp, 2018).

An organization needs a strategy to face the challenges of industrial transformation 4.0. Mergers and acquisitions (M\&A) have become a popular strategic choice for companies around the world who want to grow and develop (Bauer \& Matzler, 2014). Although it is still a controversy among scientists whether M\&A will improve or reduce company performance, many companies do cross-border mergers and there is a significant increase in postM\&A technology innovation. Bank Tabungan Pensiunan Nasional (Bank BTPN) uses M\&A strategies for the purpose of innovating to be able to face the challenges encountered in the industrial era 4.0 \{(Chen, Meng, \& Li, 2018), (McKinsey\&Company, 2020), (Stiebale, 2016)\}. This study makes the following scientific contributions: First, to find out whether the company's performance has improved after the merger. Secondly, this study can serve stakeholders to better understand Bank BTPN after merging with business opportunities offered by Bank BTPN to be sustainable and cooperate more closely (Ghobakhloo, 2019).

\section{RESEARCH METHOD}

This research is case study research is motivated by the phenomenon of the increasing prevalence of companies merging in Indonesia, as well as Bank BTPN in 2018 suddenly merged with SMBCI companies from Japan even though Bank 
BTPN had never been heard if have financial difficulties because the majority of customers are retired employees, and only serves the business of pensioners and lending to pensioners, therefore researchers are interested in conducting a case study at Bank BTPN which consists of three stages: the first stage the researcher makes a research question that is making a research question why the Bank of BTPN merged with SMBCI, and whether the merger conducted by Bank BTPN can improve the performance of the Bank BTPN. The second stage of the researcher collected data on the annual financial statements of Bank BTPN in 2018 and 2019 then conducted a literature study of articles related to the merger of Bank BTPN. In the final stage, the researchers analyzed the financial performance ratios of the Bank BTPN before and after M\&A (Ross, Westerfield, \& Jordan, 2.
Bank BTPN is a mass market bank in Indonesia that serves pensioners, micro, small and medium businesses, with branch offices throughout Indonesia. In 2019 is the first year of the Bank Tabungan Pensiunan Nasional (Bank BTPN) operating as a merged bank with Sumitomo Mitsui Banking Corporation Indonesia (SMBCI). SMBCI is a leading global corporate bank from Japan, with strong technology, large assets and large finances. The concept of my research business model is merged banks should take five actions: 1) Innovation Digital Business Banking, (2) Customer Segmentation Expansion, (3) Diversification of Products/Market, (4) Quality of Human Resources, (5) Corporate Governance.

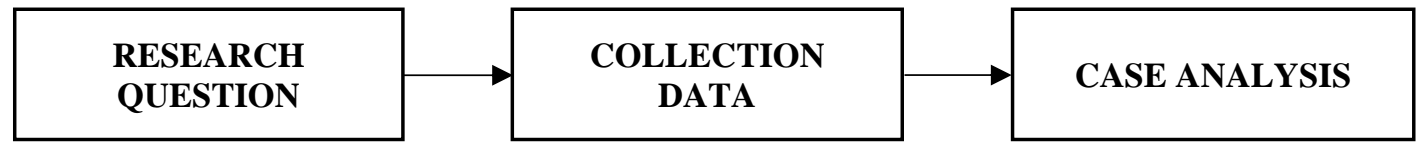

Figure 1. Methodology Scheme

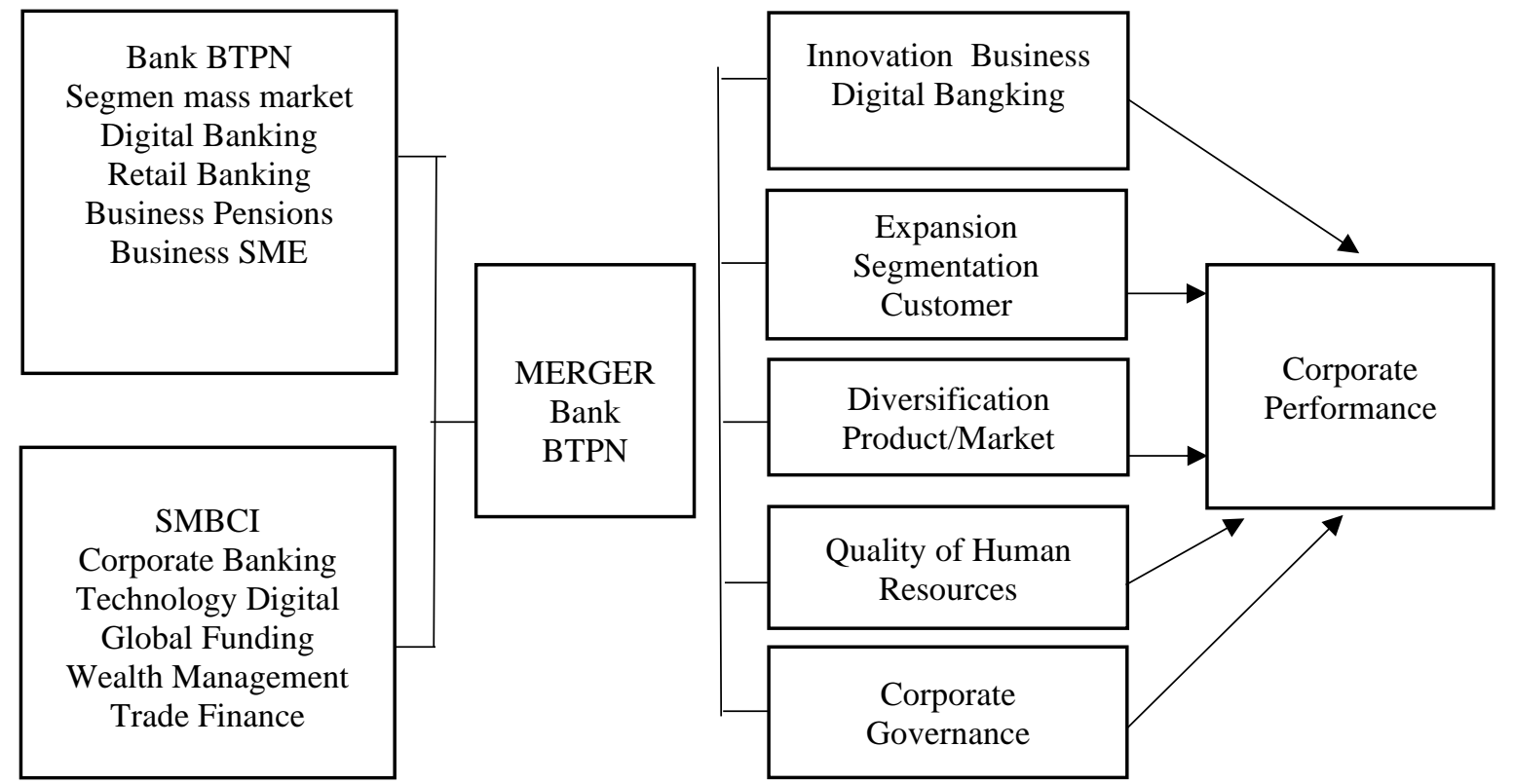

Figure 2. Business model concept merger Bank BTPN \& SMBCI

\section{RESULT AND DISCUSSION}

Implementation Industry 4.0 in all industrial sectors in both developed and developing countries still faces many obstacles due to: (1) lack of broad broadband infrastructure in realizing industry $4.0,(2)$ most companies are still reluctant to invest in $R \& D$ related to Industry 4.0, which raises very high investment requirements, (3) Lack of human resources who have the digital knowledge and skills needed to use Industry 4.0 applications, (4) lack of culture and internal digital training provided by the company to 
employees or teams to be integrated with experts, (5) The mindset and behavior of employees who do not want to change and refuse to use new technology, (6) Lack of digital strategies and scarcity of resources, (7) Change management is not effective so that it becomes a major challenge for the organization 4.0 (Raj, Dwivedi, Sharma, Lopes de Sousa Jabbour, \& Rajak, 2019).

Dephamphilis said that there were several motives for the company to carry out M\&A strategies, namely Operating Synergy (Economies of scale and scope), Financial Synergy, Diversification product/market, Strategic Realignment (Technological Change), Hubris (Managerial Pride), Buying Undervalued Asset, Managerialism (Agency Problem), Tax Consideration, Market Power and Misvaluation (DePamphilis, 2018). Ross argues that merger is absorption as a whole by one company to other companies which will provide synergy benefits because the cash flow from the combined company will be greater than the sum of the two companies' cash flows so that there will be an increase in revenue, a reduction in taxes, a reduction in taxes and a reduction in capital requirements (Ross et al., 2016). Weston argues that mergers can be interpreted as transactions that encapsulate several economic units into a new economic unit where the reasons are for increased efficiency (operational synergy and financial synergy), the impact of information and indications, reduced organizational problems, stronger market position (market share) and tax benefits (Weston, Mitchell, \& Mulherin, 2014). Referring to the opinion, as for the motive of the Bank BTPN to do a merger is to obtain synergies both operational synergy and financial synergy, technological innovation, product diversification, market power and expansion.

Though have to face an external environment that is not easy, the weakening of the economy, weakening of the Rupiah, to the uncertainty in the global market, after the merger of Bank BTPN managed to achieve a positive performance. Net profit after tax growth by $41 \%$ to Rp 2.9 trillion, the Capital Adequacy Ratio up $24.24 \%$ above the regulatory minimum 8\%, Bank BTPN's Assets increased 79\% to Rp 181.6 trillion from Rp 101.3 trillion in the previous year made Bank BTPN the 9th largest bank in Indonesia. Bank BTPN loans in 2019 growth by $108 \%$ to reach $\mathrm{Rp} 141.8$ trillion from $\mathrm{Rp} 68.1$ trillion in 2018. Liabilities increased by $82 \%$ where in 2019 it was Rp 150.2 trillion, and in 2018 it was Rp 826 trillion. Customer Deposit has increased by $23 \%$ where in 2019 it was Rp 86.9 trillion and in 2018 it was Rp 70.8 trillion. Equity increased by $68 \%$ where in 2019 amounted to $\mathrm{Rp} 31.4$ trillion and in 2018 amounted to $\mathrm{Rp} 18.8 \%$. Interest income increased by $35 \%$ where in 2019 amounted to Rp 19.1 trillion, and in 2018 amounted to $\mathrm{Rp} 14.1$ trillion. Interest expense of Rp 8.0 trillion rose $78 \%$ compared to 2028 of $\mathrm{Rp}$ 4.5 trillion. Other operating income in 2019 Rp1.6trillion increased $160 \%$ compared to the previous year of Rp 600.1 billion. Other operating expenses in 2019 Rp8.6 trillion, an increase of $18 \%$ compared to the previous year of Rp 7.3 trillion. In 2019 the Post Merger of Bank BTPN: (1) become the ninth largest bank in Indonesia in terms of assets,(2) can serve a broader range of Indonesian customers ranging from large corporations in Indonesia's main sectors to the mass market consisting of traders and producers in rural areas, (3) can take advantage of the digital banking platform, (4) can access the world's financial markets for bank financing and global technological innovation, (5) providers of wealth products to priority customers, (6) serves automotive, retail, transactional banking and payroll services for small and medium business (SME) customers, as well as (7) expansion of the reach of digital banking network services. 
Table 1. Bank BTPN

Ratio Finance

\begin{tabular}{|c|c|c|}
\hline & 2019 (Post- Merger) & 2018 (Pre-Merger) \\
\hline Asset & Rp 181,6 trillion & Rp 101,3 trillion \\
\hline Loans & Rp 141, 8 trillion & Rp 68,1 trillion \\
\hline Liabilities & $\mathrm{Rp} 150,2$ trillion & $\mathrm{Rp} 82,6$ trillion \\
\hline Deposits from Customer & $\operatorname{Rp} 86,9$ trillion & Rp 70,8 trillion \\
\hline Equity & Rp 31,5 trillion & Rp 18,8 trillion \\
\hline Interest Income & Rp 19,1 trillion & Rp 14,1 trillion \\
\hline Interest Expense & $\mathrm{Rp} 8,0$ trillion & $\mathrm{Rp} 4,5$ trillion \\
\hline Other Operating Income & Rp1,6 trillion & Rp 600,1 billion \\
\hline Other Operating Expenses & $\mathrm{Rp} 8,6$ trillion & Rp 7,3 trillion \\
\hline Income for the year before tax & Rp 4 trillion & $\mathrm{Rp} 2,9$ trillion \\
\hline $\begin{array}{l}\text { Net profit after tax attributable to } \\
\text { the parent entity }\end{array}$ & Rp 2,6 trillion & $\mathrm{Rp} 1,8$ trillion \\
\hline Loan to Deposit Ratio (LDR) & $163 \%$ & $96 \%$ \\
\hline Capital Adequacy Ratio (CAR) & $24,2 \%$ & $24,6 \%$ \\
\hline Return on Assets (ROA) & $2,3 \%$ & $3,0 \%$ \\
\hline Return on Equity (ROE) & $9,9 \%$ & $11,6 \%$ \\
\hline $\begin{array}{l}\text { Operating Expenses to Operating } \\
\text { Revenue (BOPO) }\end{array}$ & $84,5 \%$ & $80,1 \%$ \\
\hline Net Interest Margin (NIM) & $6,92 \%$ & $11,27 \%$ \\
\hline Earnings per share (EPS) & 327 & 320 \\
\hline
\end{tabular}

Source : Annual Report Bank BTPN, 2019

\section{Liquidity Ratio}

Liquidity is the ratio of liquidity to current liabilities and is a proxy for the ability of banks to repay term loans and other funds at maturity. Liquidity risk is usually associated with lower rates of return, and usually a negative relationship is expected between these variables and profitability (Kosmidou, Tanna, \& Pasiouras, 2008). Liquidity plays an important role. There are two risks in liquidity, namely the risk when excess funds where the funds in the bank are idle, this will lead to high interest rates. Second is the risk when lack of funds, as a result the funds available to meet the needs of short-term obligations are less so that they will get a penalty from the central bank. The Bank BTPN's Loan to Deposit Ratio (LDR) as at 31 December 2019 was quite high at $163 \%$, an increase of $96.2 \%$ compared to 2018 .

\section{Profitability Ratio}

Profitability is a measure of the rate of return on all equity owned by the company. Profitability describes a company's ability to benefit through all its capabilities and resources such as sales activities, cash, capital, number of employees, number of branches, etc.(Harahap, 2015). Profitability is a reflection of the benefits of financial investment. This ratio is considered by potential investors and shareholders because it relates to the price of shares and dividends to be received, therefore the level of profitability of the company is the main consideration for potential investors to determine the decision to invest in a company. After the merger, interest income in 2019 was Rp 19.1 trillion, up 35\% compared to 2018 which was Rp 14.1 trillion. Other operating income amounted to Rp1.6 trillion, up $160 \%$ compared to the previous year which was $\mathrm{Rp}$ 600.1 billion. Bank BTPN'profit before tax in 2019 ammounted to Rp 4.0 trillion, far above the 2018 achievement of Rp 2.9 trillion. Bank BTPN received net profit of $\mathrm{Rp} 2.9$ trillion, an increase of $41 \%$ compared to 2018 of Rp 2.1 trillion. Net profit after tax in 2019 amounted to Rp 2.6 trillion, an increase of $40 \%$ compared to 2018 which amounted to Rp 1.8 trillion.

\section{Corporate Performance}

Corporate Performance is the result of the implementation of company policy. Bank BTPN's corporate performance in this study was measured by ROA, ROE, BOPO, NIM and EPS. Return on Assets (ROA), Return on Equity (ROE), BOPO and NIM Ratio respectively $2.3 \%, 9.9 \%, 84.5 \%$ and $6.92 \%$. The Bank BTPN's stock price up by Rp 327,- in 2019 and Rp 320,- in 2018.

\section{CONCLUSION}

After the merger, Bank BTPN became universal bank that had a more complete business and wider customer segment from the retail to the corporate segment. Banking technology innovation in the form of the Internet of Things (Papadimitri, Staikouras, Travlos, \& Tsoumas) has succeeded in changing the 
way customers deal with banks from services through physical networks to digital banking, therefore, banking technology innovation in the field of digital banking on an ongoing basis is needed to provide more complete banking services to customers. Further research is a good idea to use panel data regression by adding samples to be able to see the impact of M\&A on company performance appropriately.

\section{Acknowledgements}

We would like to thank LPDP and Kemenristekdikti Indonesia for supporting our participation in international conference ICAISD 2020.

\section{REFERENCES}

Bauer, F., \& Matzler, K. (2014). Antecedents of M\&A success: The role of strategic complementarity, cultural fit, and degree and speed of integration. Strategic Management Journal, 35(2), 269-291. doi:https://doi.org/10.1002/smj.2091

Chen, F., Meng, Q., \& Li, X. (2018). Cross-border post-merger integration and technology innovation: A resource-based view. Economic Modelling, 68(C), 229-238. Retrieved from https://EconPapers.repec.org/RePEc:eee:ec mode:v:68:y:2018:i:c:p:229-238

DePamphilis, D. (2018). Mergers, Acquisitions, and Other Restructuring Activities. San Diego, CA, United States: Academic Press.

Ghobakhloo, M. (2019). Industry 4.0, Digitization, and Opportunities for Sustainability. Journal of Cleaner Production, 252, 119869. doi:10.1016/j.jclepro.2019.119869

Harahap, S. S. (2015). Critical Analysis toward Financial Statement. Jakarta: Raja Grafindo Persada Divisi Rajawali Pers.

Kemenperin. (2018). Making Indonesia 4.0: Strategi RI Masuki Revolusi Industri $\mathrm{Ke}-4$. Retrieved from https://kemenperin.go.id/artikel/18967/Mak ing-Indonesia-4.0:-Strategi-RI-Masuki$\underline{\text { Revolusi-Industri-Ke-4 }}$
Kosmidou, K., Tanna, S., \& Pasiouras, F. (2008). Determinants of profitability of domestic UK commercial banks: panel evidence from the period 1995-2002.

McKinsey\&Company. (2020). Realizing M\&A value creation in US banking and fintech: Nine steps for success. . Retrieved from https://www.mckinsey.com/industries/finan cial-services/our-insights/bankingmatters/realizing-m-and-a-value-creationin-us-banking-and-fintech-nine-steps-forsuccess

Nagy, J., Oláh, J., Erdei, E., Mate, D., \& Popp, J. (2018). The Role and Impact of Industry 4.0 and the Internet of Things on the Business Strategy of the Value Chain-The Case of Hungary. Sustainability, 10, 3491. doi:10.3390/su10103491

Papadimitri, P., Staikouras, P., Travlos, N. G., \& Tsoumas, C. (2019). Punished banks' acquisitions: Evidence from the U.S. banking industry. Journal of Corporate Finance, 58, 744-764. doi:https://doi.org/10.1016/j.jcorpfin.2019. 07.014

Raj, A., Dwivedi, G., Sharma, A., Lopes de Sousa Jabbour, A. B., \& Rajak, S. (2019). Barriers to the adoption of industry 4.0 technologies in the manufacturing sector: An intercountry comparative perspective. International Journal of Production Economics, 107546. doi:https://doi.org/10.1016/j.ijpe.2019.1075 $\underline{46}$

Ross, S. A., Westerfield, R., \& Jordan, B. D. (2016). Fundamentals of corporate finance.

Stiebale, J. (2016). Cross-border M\&As and innovative activity of acquiring and target firms. Journal of International Economics, 99(C), 1-15.

Weston, J. F., Mitchell, M., \& Mulherin, J. H. (2014). Takeovers, restructuring, and corporate governance. 